\title{
Layanan Bimbingan Kematangan Karir bagi Peserta Didik Berkebutuhan Khusus di SMK Inklusi
}

\author{
Serlia Wega Novitarani, Endro Wahyuno \\ Universitas Negeri Malang \\ E-mail: Serliawega@gmail.com
}

\begin{abstract}
Abstrak: Tujuan dalam penelitian ini adalah mendeskripsikan implementasi layanan bimbingan kematangan karir bagi peserta didik berkebutuhan khusus di sekolah kejuruan inklusi. Metode penelitian menggunakan pendekatan deskriptif kuantitatif dengan persentase.Sampel penelitian ini adalah seluruh guru BK, GPK dan Wali Kelas di lima sekolah kejuruan inklusi di kota Malang, yang terdapat 5 sekolah dengan respondenberjumlah39.Didapatkanhasilpenelitiandenganrata-rata(82,7\%), artinya pelaksanaan bimbingan kematangan karir di sekolah kejuruan inklusi tkota Malang telah terlaksana dengan baik. Terdapat satu pernyataan pada aspek realisasi keputusan karir yang hasilnya sebesar $40 \%$, artinya pada pernyataan tersebut belum terlaksa dengan baik. Kesimpulan bahwa peserta didik berkebutuhan khusus belum mampu mengambil keputusan mengenai masa depannya secara mandiri tanpa bimbingan dan bantuan orangtua.
\end{abstract}

Kata Kunci: Layanan bimbingan kematangan karir, peserta didik berkebutuhan khusus, SMK Inklusi

\begin{abstract}
The purpose of this study is to describe the implementation of career maturity guidance services for students with special needs in vocational schools of inclusion. The research method used quantitative descriptive approach with percentage. The sample of this research is all teachers of BK, GPK and Guardian Class in five inclusive vocational schools in Malang city, there are 5 schools with 39 respondents. The result of research with average (82,7\%), meaning that the implementation of career maturity in vocational school inclusion in Malang has done well. There is a statement on the aspect of the realization of career decisions that result in $40 \%$, meaning that the statement has not been properly. The conclusion that learners with special needs have not been able to make decisions about their future independently without the guidance and assistance of parents.
\end{abstract}

Keywords: Maturity career guidance service, children with special needs, SMK inclusion SMK

Pendidikan inklusif merupakan bentuk pendidikan yang didalamnya terdapat penerimaan Anak Berkebutuhan Khusus (ABK) yang belajar bersama dengan peserta didik non berkebutuhan khusus dalam satu sekolah dengan tujuan yaitu mengurangi diskriminasi di dalam dunia pendidikan. Seperti yang dipaparkan dalam deklarasi HAM di Salamanca tahun 1948 yang merupakan landasan adanya pendidikan inklusi menyatakan bahwa " semua orang memiliki hak atas pendidikan". Dalam hal ini ABK memiliki hak yang sama dengan semua orang dalam hal apapun, salah satunya pendidikan.

Salah satu persoalan pendidikan yang dihadapi ABK adalah upaya yang perlu dilakukan dalam menjamin pendidikan lanjut setelah ABK tersebut menyelesaikan pendidikan di tingkatan sekolah. Bagaimana mereka mampu bersaing dan dapat memiliki karir layakdi dunia yang memandang keluarbiasaan sebagai sebuah kelainan,keterbelakangan, dan bentuk-bentuk diskriminasi lainnya. Sampai kini hanya sedikit penyandang keluarbiasaan yang dapat kesempatan bersaing dan memiliki karir yang layak, mengingat kompleksnya permasalahan dan dampak yang ditimbulkan oleh keluarbiasaan. Baik yang menyangkut dampak psikologis dansosialnya.

Pada kenyataannya, perkembangan karir menjadi bagian yang yang akan melekat pada perkembangan manusia, karena itu prinsip-prinsip yang berlaku bagi perkembangan manusia pada umumnya berlaku bagi perkembangan karir. Peserta didik yang berada padamasa remaja mulai mengenal karir atau pekerjaan yang diperoleh dari lingkungan keluarga, lingkungan masyarakat, dan lingkungan sekolah. Tugas-tugas perkembangan bagi peserta didik di sekolah sebagai calon tenaga kerja ialah memilih lapangan kerja yang sesuai dengan potensi-potensi yang dimilikinya, keterampilan berfikir, kemampuan kerja dan sikap terhadap pekerjaan, tetapikenyataanya semakin menjelang kelulusan peserta didik masih banyak yang bingung akan tindak lanjut setelah mereka lulus sekolah. Pemahaman peserta didik terhadap diri dan dunia kerja, serta terbatasnya kesempatan untuk mengamati bidang pekerjaan yang ada dimasyarakat, mengakibatkan peserta didik membuat keputusan karir yang terlalu cepat (Brown, 1984). Keputusan karir merupakan keterampilan yang dapat dipelajari, sehingga dapat diberikan disekolah (Hansen \& Crammer, 1971). Untuk dapat merencanakan karir yang akurat dan cermat di sekolah perlu memprogramkan pemberian bimbingan bagi peserta didik untuk perkembangan karirnya.

Permasalahan ini sering terjadi pada peserta didik lulusan SMK. Mereka akan dihadapkan pada situasi 
pilihan, yaitu: melanjutkan studi ke perguruan tinggi atau harus memasuki dunia kerja. Masalah yang terjadi pada peserta didik dalam rangka persiapan memasuki dunia kerja diantaranya peserta didik belum mampu mengembangkan karirnya ketika sesudah memilih jurusan sesuai dengan yang dipilihnya di sekolah. Dibandingkan dengan Sekolah Menengah Atas (SMA), sekolah kejuruan seperti SMK mempunyai perbedaan yang mendasar. SMK memiliki dua ciri khas, yaitu: pertama lulusan SMK mampu mengisi peluang kerja didunia usaha/ dunia industri karena lulusannya memiliki sertifikasi melalui uji kompetesi, kemudian lulusan SMK bisa melanjutkan keperguruan tinggi selama lulusantersebut memenuhi persyaratan, dalam segi nilai maupun program studi atau jurusan sesuai dengan kreteria yang disyaratkan(Supardi: 2008). Dengan dua keunggulan tersebut, pendidikan di SMK dikenal dengan Pendidikan Sisem Ganda (PSG). Namun, lulusannya lebih diharapkan untuk kesiapan dalam memasuki dunia kerja nantinya.

Sejalan dengan kondisi tersebut, guru pembimbing di sekolah menengah harus proaktif memberikan bimbingan kepada peserta didik selama masa pendidikan di sekolah, karenapembimbing memiliki peran penting yaitu sebagaisalah satu komponen student support service yang mendukung perkembangan aspek- aspek pribadi, sosial karir, dan akademik peserta didik, melalui pengembangan menu program bimbingan dan konseling pembantuan kepada peserta didik. Dengan berbagai permasalahan yang dihadapi peserta didik dalam menentukan karirnya, diartikan bahwa peserta didik tersebut belum memiliki kematangankarir. Kematangan karir merupakansalah satu bentuk program layanan dalam bimbingan karir. Tujuan dari program bimbingan kematangan karir adalah membantu individu agar dapat mengenal dan memahami potensi dirinya dan menganal tentang dunia kerja sehingga individu tersebut mampu mengambil keputusanakankariryangdikehendakidan sesuai dengan potensi dirinya. Seperti pendapat Winkel (2005) bahwapeserta didik seringkali mengalami kebingungan, keraguan, serta kesulitan untuk mempersiapkan diri dalam memilih program studi di perguruan tinggi dan memasuki dunia kerja bila ia tamat dari SMA atau sekolah yang sederajat. Sehingga para peserta didik terutama peserta didik berkebutuhan khusus yang akan melanjutkan pelajaran, atau memilih program studi, serta yang akan langsung melanjutkan ke dunia kerja, memerlukan bimbingan karir yang terarah sehingga peserta didik berkebutuhan khusus memiliki kematangan karir yang baik.

Salah satu kota pendidikan inklusi adalah kota Malang. Pendidikan Inklusif yang ada di Kota Malang ada pada berbagai tingkat pendidikan mulai dari pendidikan dasar, menengah, hingga perguruan tinggi. Menurut dinas pendidikan kota malang sekolahmenengah kejuruan yang menyelenggarakan inklusi tahun 2015 berjumlah 5 sekolah yaitu
SMKN 2, SMKN 7, SMKN 9, SMKN13, dan SMK Tunas Bangsa Malang. Alasan peneliti mengambil penelitian layanan bimbingan kematangan karir bagi peserta didik berkebutuhan khusus pada jenjang Sekolah Menengah Kejuruan (SMK) adalah karena sekolah menengah kejuruan sebagai wadah pendidikan formal dalam menyiapkan peserta didik memasuki dunia kerja. Kesiapan kerja yang dimilikipeserta didik diksesuai dengan potensi dalam berbagai pekerjaan yang dapat langsung diterapkan. Contoh awal peserta didik akan memiliki pengalaman nyata pada dunia kerja melalui Praktik Kerja Industri(Prakerin).

Dengan adanya praktik kerja industri (prakerin) sekolah menengah kejuruan maka menjadi permulaan latihan dalam dunia kerja maupun untuk bermasyarakat.Terlebih lagi untuk peserta didik berkebutuhan khusus yang memiliki hambatan secara fisik, intelektual maupun sosial akan lebih sulit ketika terjun ke masyarakat dan bersaing dalam dunia kerja. Dari pengalaman KPL selama satu setengah bulan di salah satu SMALB kota Malang, orang tua peserta didik berkebutuhan khusus yang telah lulus cenderung meminta bantuan atau rekomendasi dari pihak sekolah untuk mencarikan tempat kerja bagi anaknya. Sehingga menjadi sangat penting untuk diketahui layanan bimbingan kematangan karir yang diberikan untuk peserta didik berkebutuhan khusus di sekolah dalam menyongsong masa depannya di dalam dunia kerja. Melalui pemaparan diatas, maka peneliti tertarik untuk mengambil judul "Implementasi Layanan Bimbingan Kematangan Karir bagi Peserta Didik Berkebutuhan Khusus di Sekolah Kejuruan Penyelenggara Inklusi di Kota Malang”.

\section{METODE}

Penelitian ini menggunakan pendekatan kuantitatif dengan jenis penelitian Deskriptif. Pelaksanaan penelitian dimulai pada bulan Mei hingga Juli 2017 di SMK inklusi di kota Malang. Penelitian ini memiliki subjek penelitian sebanyak 39 responden yang terdiri dari guru BK, GPK, dan wali kelas peserta didik berkebutuhan khusus. Metode yang digunakan untuk mengumpulkan data adalah skala Guttman. Dalam penelitian ini digunakan item skala yang berbentuk pernyataan dan sifatnya tertutup. Skala guttman yang digunakan dalam penelitian ini adalah implementasi layanan bimbingan kematangan karir bagi peserta didik berkebutuhan khusus yang di lakukan oleh guru BK,GPK, dan Wali kelas. Uji validitas menggunakan Pearson Correlation dengan piranti lunak SPSS 16 butir item disusun berdasarkan pelaksanaan dilapangan yang mungkin dilakukan oleh ketiga responden yang dituju. Hail realibilitas didapatkan dengan menggunakan perhitungan Cronbach Alpha yang dihitung menggunakan SPSS 16.

Data dalam penelitian ini diolah menggunakan 
teknik statistik deskriptif. Analisis data dilakukan untuk mengetahui mean dari implementasi layanan bimbingan kematangan karir bagi peserta didik berkebutuhan khusus yang dilakukan oleh responden. Perhitungan statistic dilakukan menggunakan piranti lunak SPSS 16 for windows. Peneliti mengkategorikan keberhasilan layanan bimbingan kematangan karir pada setiap item pernyataan kedalam tiga kategori yaitu telah terlaksana, belum terlaksana dan tidak terlaksana. Namun, untuk menarik kesimpulan dari keberhasilan layanan bimbingan kematangan karir sesuai dengan sub indikator yang ada peneliti mengkategorikan subyek penelitian menjadi lima, yaitu sangat tinggi, tinggi, sedang, rendah, dan sangat rendah. Dengan batasan kategorisasi persentase sebagai berikut, 0\%-20\% sangat rendah, 21\%-40\% rendah, 41\%-60\%sedang, $61 \%-80 \%$ tinggi, dan $81 \%$ $100 \%$ sangat tinggi.

\section{HASIL DAN PEMBAHASAN}

\section{Hasil}

Data yang diperoleh merupakan hasil analisis persentase dari sub variabel kematangan karir. Skala ini digunakan untuk mengetahui implementasi layanan bimbingan kematangan karir peserta didik berkebutuhan khusus di sekolah menengah kejuruan inklusi di kota Malang. Peneliti mengkategorikan keberhasilan layanan bimbingan kematangan karir pada setiap item pernyataan kedalam tiga kategori yaitu telah terlaksana, belum terlaksana dan tidak terlaksana. Namun , untuk menarik kesimpulan dari keberhasilan layanan bimbingan kematangan karir sesuai dengan sub indikator yang ada peneliti mengkategorikan subyek penelitian menjadi lima, yaitu sangat tinggi, tinggi, sedang, rendah, dan sangat rendah. Dengan batasan kategorisasi persentase sebagai berikut, $0 \%-20 \%$ sangat rendah, $21 \%-40 \%$ rendah, 41\%-60\%sedang, 61\%-80\% tinggi, dan 81\%-100\% sangat tinggi.

Indikator pertama terdapat 3 sub indiator. Pertama yaitu menyadari wawasan dan persiapan karir diperoleh hasil sebesar 74,35\%, artinya bahwa pelaksanaan bimbingan dikategorikan tinggi atau diartikan telah terlaksana. Kemudian yang kedua yaitu langkah dalam persiapan perencanaan karir diperoleh hasil sebesar $100 \%$, bahwa pelaksanaan bimbingan dikategorikan sangat tinggi atau diartikan telah terlaksana sangat baik disemua sekolah. Dan yang terakhir yaitu memiliki perencanaan karir dimasa depan diperoleh hasil sebesar 84,61\%, artinya bahwa pelaksanaan bimbingan dikategorikan sangat tinggi atau diartikan telah terlaksana sangat baik disemua sekolah sebagai responde.

Indikator Kedua terdapat $2 \mathrm{sub}$ indiator. Pertama yaitu menyadari mengumpulkan informasi karir dari berbagai sumber diperoleh hasil sebesar 79,48\%, artinya bahwa pelaksanaan bimbingan dikategorikan tinggi atau diartikan telah terlaksana. Kemudian sub yang kedua yaitu mengumpulkan informasi karir dari berbagai sumber karir diperoleh hasil sebesar $89,74 \%$, artinya bahwa pelaksanaan bimbingan dikategorikan sangat tinggi atau diartikan telah terlaksana sangat baik disemua sekolah sebagai responden. Hal ini menunjukkan bahwa siswa sudah mampu megeksplorasi karir dengan orang lain, mengeksplorasi kemampuan diri yang sesuai dengan karir serta mengeksplorasi kegiatan yang mendukung karir.

Indikator Ketiga terdapat $2 \mathrm{sub}$ indiator. Pertama yaitu mengetahui cara dan langkah membuat keputusan karirdari orang lain diperoleh hasil sebesar 79,48\%, artinya bahwa pelaksanaan bimbingan dikategorikan tinggi atau diartikan telah terlaksana. Kemudian yang kedua yaitu menentukan keputusan karir yang tepat diperoleh hasil sebesar $80,77 \%$, artinya bahwa pelaksanaan bimbingan dikategorikan sangat tinggi atau diartikan telah terlaksana sangat baik disemua sekolah sebagairesponden.

Indikator Keempat terdapat 4 sub indiator. Pertama yaitu mengetahui minat dan kemampuan dalam menunjang pekerjaan diperoleh hasil sebesar 70,51\%, artinya bahwa pelaksanaan bimbingan dikategorikan tinggi atau diartikan telah terlaksana. Kemudian yang kedua yaitu mempelajari hal-hal yang berkaitan dengan pekerjaan yang dipilih melalui orang lain diperoleh hasil sebesar 80,34\%, artinya bahwa pelaksanaan bimbingan dikategorikan sangat tinggi atau diartikan telah terlaksana sangat baik disemua sekolah sebagai responden. Ketiga yaitu mengetahui tugas pekerjaan dalam suatu jabatan diperoleh hasil sebesar 92,3\%, artinya bahwa pelaksanaan bimbingan dikategorikan sangat tinggi atau diartikan telah terlaksana sangat baik di semua sekolah sebagai responden. Dan yang keempat yaitu mengetahui sikap dan perilaku dalam bekerja diperoleh hasilsebesar $82,05 \%$, artinya bahwa pelaksanaan bimbingan dikategorikan sangat tinggi atau diartikan telah terlaksana sangat baik disemua sekolah sebagai responden. Hal ini menunjukkan siswa mampu mengetahui kapasitas diri yang dibutuhhkan sesuai dengan karir tertentu dan mampu mencari dan menggali informasi seputar karir yang diminati.

Indikator Kelima terdapat $5 \mathrm{sub}$ indiator. Pertama yaitu pemahaman peserta didik mengenai tugas dan bidang jurusan yang dipilih diperoleh hasil sebesar 78,2\%, artinya bahwapelaksanaan bimbingan dikategorikan tinggi atau diartikan telah terlaksana. Kemudian yang kedua yaitu pemahaman peserta didik mengenai tugas dan bidang pekerjaan yang diinginkan diperoleh hasil sebesar 98,29\%, artinya bahwa pelaksanaan bimbingan dikategorikan sangat tinggi atau diartikan telah terlaksana sangat baik disemua sekolah sebagai responden. Ketiga yaitu mengetahui persyaratan pekerjaan yang diinginkan diperoleh hasil sebesar 94,87\%, artinya bahwa pelaksanaan 
bimbingan dikategorikan sangat tinggi atau diartikan telah terlaksana sangat baik disemua sekolah sebagai responden. Keempat yaitu mengetahui faktor dan alasan yang mempengaruhi pilihan pekerjaan peserta didik diperoleh hasil sebesar $88,46 \%$, artinya bahwa pelaksanaan bimbingan dikategorikan sangat tinggi atau diartikan telah terlaksana sangat baik disemua sekolah sebagai responden. Dan yang kelima yaitu mengidentifikasi resiko pada pekerjaan yang diminati peserta didik diperoleh hasil sebesar $89,74 \%$, artinya bahwa pelaksanaan bimbingan dikategorikan sangat tinggi atau diartikan telah terlaksana sangat baik disemua sekolah sebagai responden.

Indikator Keenam terdapat 2 sub indiator. Pertama yaitu memahami kekuatan dan kelemahan diri dalam menunjang keputusan karir diperolehhasil sebesar $76,92 \%$, artinya bahwa pelaksanaan bimbingan dikategorikan tinggi atau diartikan telah terlaksana. Kemudian kedua yaitu mengetahui faktor pendukung dan penghambat kelanjutan keputusan karir peserta didik diperoleh hasil sebesar 79,48\%, artinya bahwa pelaksanaan bimbingan dikategorikan tinggi atau diartikan telah terlaksana dengan baik disemua sekolah sebagai responden. Dan yang ketiga yaitu kemandirian dalam mengambil keputusan karir setelah lulus sekolah diperoleh hasil sebesar $67,94 \%$, artinya bahwa pelaksanaan bimbingan dikategorikan tinggi atau diartikan telah terlaksana dengan baik disemua sekolah sebagai responden.

\section{Pembahasan}

Berdasarkan hasil data yang telah diperoleh, bahwa pelaksanaan layanan bimbingan kematangan karir bagi peserta didik berkebutuhan khusus di SMK inklusi di kota Malang telah diperoleh hasil persentase dengan kategori tinggi hingga sangat tinggi yaitu antara 60\%$100 \%$ dengan rata-rata hasil persentase yaitu $82,7 \%$, artinya bahwa SMK di kota malang telah memberikan bimbingan kepada peserta didik berkebutuhankhusus dengantujuanagarmerekadapatmemiliki kematangan karir yang baik. Pada keenam indikator kematangan karir yang memiliki hasil porsentase terendah adalah pada indikator realisasi karir dalam pengambilan keputusan yaitu diperoleh hasil 74\%. Penyebab peserta didik berkebutuhan khusus belum mampu mandiri dalam pengambilan keputusan, yaitu faktor orang tua menjadi lebih dominan. Hal ini menunjukkan bahwa efikasi diri peserta didik masih belum berkembang. Sesuai dengan pendapat dari Seligman (Komandyahrini \& Hawadi, 2008) bahwa salah satu ciri tingkat kematangan karir yang positif ditandai dengan meningkatnya sikap yang berhubungan dengan kematangan karir yakni efikasi diri. Kemudian rata-rata tertinggi yaitu pada indikatorpengetahuan kelompok pekerjaan yang lebih disukai, yaitu diperoleh data sebesar $88 \%$, artinya peserta didik lebih cenderung tertarik padapekerjaan yang sesuai dengan kemampuan dan kegemarannya. Siswa mampu menangkap keunggulan dan kekurangan diri yang ada pada dirinya untuk mampu merencanakan karir dimasa depan secara matang dan sesuai dengan kemampuan diri. Salah satu tugas perkembangan remaja adalah memilih dan menyiapkan karir di masa yang akan datang. perkembangan karir mereka memasuki tahap perencanaan yaitu terutama bersifat kognitif dengan meninjau diri sendiri dan situasi hidupnya.

\section{KESIMPULAN DAN SARAN}

\section{Kesimpulan}

Berdasarkan pemaparan analisis data yang telah dibahas, penelitian ini membuktikan bahwa implementasi layanan bimbingan kematangan karir bagi peserta didik berkebutuhan khusus di sekolah kejuruan inklusi di kota malang telah terlaksana dengan baik, karena telah diperoleh hasil sebesar $82,7 \%$ dari setiap indikator yang ada. Pada indikator perencanaan karir diperoleh hasil sebesar $86 \%$, indikator yang kedua yaitu eksplorasi karir diperoleh $84 \%$, kemudian indikator yang ketiga pengetahuan membuat kaputusan karir diperoleh hasil sebesar 79,5\%, kemudian pada indikator yang keempat yaitu pengetahuan (informasi) dunia kerja di peroleh rata-rata sebesar $81 \%$, kemudian pada indikator yang kelima yaitu pengetahuan kelompok pekerjaan yang lebih disukai diperoleh rata-rata sebesar $88 \%$, dan pada indikator keenam yaitu realisasi karir dalam pengambilan keputusan diperoleh data sebesar 74\%. Hal ini menunjukkan bahwa SMK inklusi dengan baik, karena data yang ada telah menunjukkan rata-rata pelaksanaan pada setiap indikator kematangan karir berada pada kategori tinggi hingga sangattinggi.

\section{Saran}

Berdasarkan pemaparan hasil data penelitian, beberapa saran untuk memperbaiki hasil yang telah didapat Guru BK disarankan untuk lebih banyak memberikan bimbingan maupun konseling terhadap siswa mengenai efikasi diri dan kematangan karir. Bimbingan maupun konseling efikasi diri berupa penguatan akan keyakinan diri yang dimiliki, tidak mudah menyerah menghadapi kegagalan, serta mampu menghadapi berbagai situasi permasalahan yang komplek, serta bimbingan atau konseling kematangan karir yang berupa perencanaan karir, eksplorasi karir, informasi karir, pengambilan keputusan karir, dan pandangan orientasi pada suatu bidang karir tertentu. Guru BK bisa juga membimbing siswa dalam perencanaan karir dengan cara membuat media-media seperti pamplet, poster, atau papan bimbingan yang berhubungan dengan karir siswa di masa depan.

Penelitian ini dimaksudkan untuk memahami 
permasalahan siswa,khususnya yang berhubungan dengan efikasi diri dan kematangan karir. Bagi penelitiselanjutnya yang akan melakukan penelitian serupa, penelitian ini dapat dijadikan tambahan referensi untuk penelitian selanjutnya dan diharapkan peneliti untuk lebih dapat memperhatikan factor factor lain yang mempengaruhi. Peneliti selanjutnya juga diharpakan dapat mengembangkan alat ukur penelitian yang lebih detail secara lebih menyeluruh dan mendalam.

\section{DAFTAR RUJUKAN}

Dewa K. S. (1984). Bimbingan Karir Di SekolahSekolah, Jakarta: Proyek Buku Terpadu Jakarta, Pusat Perbukuan Depdikbud SPK No.890/3006 Dan Proyek Peningkatan Pendidikan Kejuruan Non.Teknik II.
Winkel W. S. \& Hastuti S. (2005). Bimbingan dan Konseling di Institusi Pendidikan. Yogyakarta: FKIP Universitas SanataDharma.

Gufron M. N. \& Risnawita R. (2010). Teori-teori Psikologi. Jakarta: Ar-RuzMedia.

Priyatno Dan Erman Anti.1999. Dasar- Dasar Bimbingan Dan Konseling, Jakarta: Renika Cipt

Proceding ICSAR. 2017. Reorientation Of Special Education In Improving Self-Help Of Children With Special Education, Malang: FIP Universitas Negeri Malang (7 th series 2017). p. 287. 